\title{
Analysis of Performance Indicators City Transport Services in Palu City
}

\author{
Jurair Patunrangi ${ }^{1, *}$, and Syamsul Arifin ${ }^{1}$ \\ ${ }^{1}$ Tadulako University, Civil Engineering Department, Jl. Soekerno Hatta, Palu, Indonesia, 94118
}

\begin{abstract}
The transportation system in the city of Palu adheres to the door to door service system. Getting city transportation is very difficult. This study discusses the operating performance of urban public transport vehicles, based on the standards of the Ministry of Transportation and the World Bank. Data were collected through a series of field surveys in 3 zones of the study area, which included headway, waiting time, number of passengers, speed and load factor. The results of data analysis show that headway average city transportation varies (minutes) zone 1 (12:25 $27: 18)$, zone $2(<5$ minutes 8 segments $(26.67 \%), 5$ to 10 minutes 13 segments $(43.33 \%)$ and $>15$ minutes 9 segments $(30,00 \%))$. zone $3(10: 35$ - 28:14), waiting time (minutes) zone 1 (6:13 - 13:50), zone 2 (0:56 19:38) and zone $3(5: 25-12: 20)$, passengers at peak zone 1 time average 3.21 , zone 2 is not measurable and zone 3 averages 4.18 passengers, zone 1 speeds average $36.16 \mathrm{~km} / \mathrm{h}$, zone 2 is not measurable and zone 3 on average $35,23 \mathrm{~km} /$ hour, zone 1 load factor averages $35.65 \%$, zone 2 is not measurable and zone 3 averages an average of $45.19 \%$.
\end{abstract}

${ }^{*}$ Corresponding author: syam_arfn@yahoo.com 


\section{Introduction}

The role of transportation is a very important element in supporting urban activities, [1]. This has an effect on changes in regional structures which tend to lead to the formation of many central spatial structures [2]. There is also the phenomenon of urban sprawl which is characterized by the development of areas with low density and symptoms of changes in land in the outskirts of the administrative area [3].

Demands for high mobility in urban areas are not balanced with good transportation system services with the concept of sustainable transportation. [4]. The phenomenon that arises related to this imbalance, among others, is the tendency to swell the number of ownership and travel of private vehicles that are not balanced by the infra-structure of road networks resulting in congestion, delays, waste of energy and costs, and air pollution and noise (noise) [5]. In addition, the presence of inadequate public transportation and far from being efficient because it still has a low capacity, resulting in wasteful costs and excessive energy resources. [6-7]. Paratransit is a vehicle that is operated with no fixed schedule and route and can stop (raise and lower passengers) along its route. Based on [8] paratransit is an urban transport service on public roads with traffic flow mixed and provided by public or private operators for use by certain groups of users.

\section{Study Location}

The city transportation service system in Palu City has been regulated based on the Mayor's Decree, where the beginning and end of the trip are set at the terminal or end at the end of the trip by crossing the designated route. As a result of the non-implementation of the route, it causes problems in the service performance of transportation infrastructure such as; decrease in speed, delay in travel, symptoms of traffic jams on certain road segments and disruption to the environment in the form of; air pollution, and vibration.

Table 1. Total Population and Population Density of Sub-districts in Palu City.

\begin{tabular}{|c|c|c|c|}
\hline Sub-district & $\begin{array}{c}\text { Total } \\
\text { Population } \\
\text { (People) }\end{array}$ & $\begin{array}{c}\text { Area } \\
\text { (km2) }\end{array}$ & $\begin{array}{c}\text { Population } \\
\text { Density } \\
\text { (People/Km2) }\end{array}$ \\
\hline Ulujadi & 26.883 & 40,25 & 668 \\
\hline Palu Barat & 60.458 & 8,28 & 7302 \\
\hline Tatanga & 38.743 & 14,95 & 2592 \\
\hline Palu Selatan & 68.385 & 27,38 & 2498 \\
\hline Palu Timur & 68.674 & 7,71 & 8907 \\
\hline Mantikulore & 61.826 & 206,80 & 299 \\
\hline Palu Utara & 22.473 & 29,94 & 751 \\
\hline Tawaeli & 19.900 & 59,75 & 333 \\
\hline Total & 367.342 & 395,06 & 930 \\
\hline
\end{tabular}

The largest population is in the East Palu sub-district, which is 68,674 people, followed by the South Palu sub-district with a population of 68,385 inhabitants, while the smallest population is Tawaeli sub-district with 19,900 inhabitants [10].

\section{Methodology}

Analysis of the performance indicators services is carried out based on the division of zones according to the current service system and the density level of the urban road network. 
The description of this is explained as follows:

- Zone 1 (Ulujadi), as an exit/entry gate to Donggala district served by 1 route where most of the population lives along the coast on the state road corridor which also functions as a city transportation route, there is a Manonda terminal (type C) which functions as the intermediate terminal and the beginning / end terminal of a trip.

- Zone 2 (West Palu, Tatanga, South Palu and East Palu), as a central area of the city, most of the area is affordable with various types of 2-wheeled and 4-wheeled vehicles because it is equipped with road network infrastructure such as state roads, provincial roads and city roads. The area is equipped with 2 type $\mathrm{C}$ terminals, namely (Masomba and Petobo). Most areas have not been reached by city transportation such as: Donggala Kodi, Balaroa, Duyu, Petobo, Kawatuna and Lasoani.

- Zone 3 (Tawaeli, North Palu and Mantikulore), as the exit/entry gate to Donggala district and Parigi Moutong district, also served by 1 route where most of the population lives along the coast on the state road corridor. In this road corridor there is a Mamboro terminal (type B) which serves as the initial and final terminal of a journey and a terminal between city transportation.

\subsection{Public Transport Performance Indicators}

Until now there has been no standard regarding the performance of city transportation, one of the references that can be used in evaluating public transport is to use the standards of the Directorate General of Land Transportation in its explanation of issuing indicators of quality of public transport services as follows:

A number of things need to be known in relation to the quality and quantity of passenger public transport services, including the volume of traffic to be traversed, the frequency and scheduling of services, the expected length of travel, the degree of travel interest, and the transportation costs charged [11].

Table 2. Criteria for Urban Public Transport Services

\begin{tabular}{|c|c|}
\hline Criteria & Size \\
\hline Waiting Time & $5-10$ minute \\
Average Maximum & $10-20$ minute \\
\hline Walking distance to the shelter & \\
dense region & $300-500$ meter \\
Less dense region & $500-1000$ meter \\
\hline Mode change time & $0-1$ times \\
Average Maximum & 2 times \\
\hline Bus travel time & $1-1,5$ hours \\
Average Maximum & $2-3$ hours \\
\hline Bus travel speed & $10-12 \mathrm{kph}$ \\
Dense areas and mixed traffic & $15-18 \mathrm{kph}$ \\
With a special bus lane & $25 \mathrm{kph}$ \\
Less dense areas & $10 \%$ \\
\hline Travel expense & \\
From average income & \\
\hline
\end{tabular}

\subsection{Evaluation Parameters}

The evaluation parameters used in this study include:

1). Total passenger 
The number of passengers in question is the number of passengers carried by one urban public transportation in one day passengers / transportation / day).

2). Load factor

According to the Decree of the Director General of Land Number: SK.687 / AJ.206 / DRDJ / 2002, the load factor is the ratio of the number of passengers per transport capacity on public transport, that can be obtained by the formula:

$$
L F=(J P / C) \times 100 \%
$$

where: $\mathrm{LF}=$ Load Factor $(\%), \mathrm{JP}=$ Number of Passengers (person)

$\mathrm{C}=$ Transport Capacity (person)

3) Number of Fleet

The number of fleets in accordance with the needs is difficult to ascertain, what can be done is an amount that is close to the size of the need.

The number of fleets can be calculated as follows.

a. Vehicle capacity

Vehicle capacity is the passenger load capacity of each public transport vehicle. The vehicle capacity of each type of public transport can be seen in Table 3, below:

Table 3. Vehicle Capacity

\begin{tabular}{|c|c|c|c|c|}
\hline \multirow{2}{*}{ Type of Vehicle } & \multicolumn{3}{|c|}{ Vehicle Capacity } & $\begin{array}{c}\text { Passenger } \\
\text { Capacity } \\
\text { day/vehicle }\end{array}$ \\
\cline { 2 - 5 } & Sit & Stand & Total & $250-300$ \\
\hline Passenger car & 9 & - & 9 & $300-400$ \\
\hline Small bus & 14 & - & 14 & $1.000-1.200$ \\
\hline Single floor big bus & 49 & 30 & 79 & $1.500-1.800$ \\
\hline Double floor big bus & 85 & 38 & 120 & \\
\hline
\end{tabular}

b. Circulation time

Circulation time with an average vehicle speed setting of $20 \mathrm{~km}$ per hour with a time deviation of $5 \%$ of the travel time. The circulation time is calculated by the formula:

$$
\mathrm{CTABA}=(\mathrm{TAB}+\mathrm{TBA})+(\sigma \mathrm{AB}+\sigma \mathrm{BA})+(\mathrm{TTA}+\mathrm{TTB})
$$

where: $\mathrm{CTABA}=$ Circulation Time from $\mathrm{A}$ to $\mathrm{B}$ back to $\mathrm{A}, \mathrm{TAB}=$ Average Travel Time from $\mathrm{A}$ to $\mathrm{B}, \mathrm{TBA}=$ Average Travel Time from $\mathrm{B}$ to $\mathrm{A}, \sigma \mathrm{AB}=$ Deviation of Travel Time from $\mathrm{A}$ to $\mathrm{B}, \sigma \mathrm{BA}=$ Deviation of Travel Time from $\mathrm{B}$ to A, TTA $=$ Vehicle Stop Time in A, TTB = Vehicle Stop Time at B.

c. Stop Time

The stop time for vehicles at origin or destination (TTA or TTB) is set at $10 \%$ of the travel time between $\mathrm{A}$ to $\mathrm{B}$.

d. Time Between Vehicles

The time between vehicles is determined based on the following formula:

$$
\mathrm{H}=(60 \times \mathrm{C} \times \mathrm{LF}) / \mathrm{JP}
$$

where: $\mathrm{H}=$ Intermediate Time (minutes), $\mathrm{JP}=$ number of passengers per hour in the section contained, $\mathrm{C}=$ Vehicle Capacity, $\mathrm{LF}=$ Load Factor, taken $70 \%$ (under dynamic conditions) 
e. Number of Circulation Time Fleet

The number of circulation time fleet required is calculated by the formula:

$$
\mathrm{K}=\mathrm{CT} /(\mathrm{H} \times \mathrm{fA})
$$

where: $\mathrm{K}=$ Number of Vehicles, $\mathrm{Ct}=$ Circulation Time (minutes)

$\mathrm{H}=$ Intermediate Time (minutes), $\mathrm{fA}=$ Vehicle Availability Factor $(100 \%)$

4) Headway and Frequency

Headway is the time or distance between one other public transportation vehicle which is successively behind it on the same route. To obtain the headway value, the following formula is used:

$$
\mathrm{H}=\mathrm{T} 2-\mathrm{T} 1
$$

where: $\mathrm{H}=$ Headway (minutes), $\mathrm{T} 1=$ First Vehicle Time,

$\mathrm{T} 2=$ Second Vehicle Arrival Time

The headway that has been obtained is then averaged to get an average headway that represents the headway of an urban transport lane. Frequency is the number of vehicle trips in a certain time unit which can be identified as high and low frequencies. Frequency can be calculated by the formula:

$$
\mathrm{F}=60 / \mathrm{H}
$$

where: $\mathrm{F}=$ Frequency, $\mathrm{H}=$ Headway

5). Travel speed

Travel speed is the ratio between the distance traveled by the transportation and the time it takes for the transport to perform services.

$$
\mathrm{F}=\mathrm{S} / \mathrm{T}
$$

where: $\mathrm{V}=$ Travel speed $(\mathrm{km} / \mathrm{h}), \mathrm{S}=$ Route Length, $\mathrm{T}=$ Travel Time

\subsection{Analysis of City Transportation Performance Indicator Measurement}

The data needed to measure performance indicators is obtained from static and dynamic survey results in the form of a headway between the arrival of the vehicle. [12]. The performance indicators to be measured are: a. Waiting time for passengers, $b$. Traveling time, c. Speed, d. Load Factor, and e. Frequency

\section{Results and Discussion}

Public transport performance depends on transportation in running the fleet both to regulate speed, travel time and in passenger service. In addition, passenger performance is also influenced by the characteristics of the road or route that the transportation takes.

\subsection{Data Processed Results}

The processed data related to the performance indicators of city transportation services with microbuses in the city of Palu are; headway, passenger waiting time, speed, load factor and service frequency are presented as follows: 
Table 4. City Transportation Headway and Waiting Times of two Segments in Zone-1 and Sub District Tatanga and South Palu in Zone-2

\begin{tabular}{|c|c|c|c|c|c|c|}
\hline \multirow{2}{*}{$\begin{array}{c}\text { Indicator } \\
\text { Performances }\end{array}$} & \multicolumn{3}{|c|}{ Segment-1 } & \multicolumn{3}{|c|}{ Segment-2 } \\
\hline & Morning & Noon & Afternoon & Morning & Noon & Afternoon \\
\hline & \multicolumn{6}{|c|}{ Zone-1 } \\
\hline Headway & 17,12 & 27,18 & 21,00 & 12,25 & 19,44 & 13,16 \\
\hline \multirow[t]{3}{*}{ Waiting Time } & 8,56 & 13,59 & 10,50 & 6,13 & 9,58 & 6,58 \\
\hline & \multicolumn{6}{|c|}{ Zone- 2 (Tatanga) } \\
\hline & \multicolumn{3}{|c|}{ Internode-4 } & \multicolumn{3}{|c|}{ Internode-5 } \\
\hline Headway & 10,93 & 4,07 & 7,32 & 18,00 & 15,50 & 23,00 \\
\hline \multirow[t]{3}{*}{ Waiting Time } & 5,47 & 2,03 & 3,66 & 9,00 & 7,75 & 11,50 \\
\hline & \multicolumn{6}{|c|}{ Zone- 2 (South Palu) } \\
\hline & \multicolumn{3}{|c|}{ Internode- 6} & \multicolumn{3}{|c|}{ Internode-7 } \\
\hline Headway & 18,50 & 12,38 & 11,00 & 12,38 & 11,73 & 11,50 \\
\hline Waiting Time & 9,25 & 6,19 & 5,50 & 6,19 & 5,86 & 5,75 \\
\hline
\end{tabular}

Table 5. City Transportation Headway and Waiting Times in Eastern and Western Palu of Zone-2 and Three Segments in Zone-3

\begin{tabular}{|c|c|c|c|c|c|c|c|c|c|}
\hline \multirow{3}{*}{$\begin{array}{c}\text { Indicator } \\
\text { performances }\end{array}$} & \multicolumn{9}{|c|}{ Zona-2 (Eastern Palu) } \\
\hline & \multicolumn{3}{|c|}{ Internode-1 } & \multicolumn{3}{|c|}{ Internode-2 } & \multicolumn{3}{|c|}{ Internode-3 } \\
\hline & Morning & Noon & Afternoon & Morning & Noon & Afternoon & Morning & Noon & Afternoon \\
\hline Headway & 10,32 & 6,10 & 8,50 & 38,00 & 28,75 & 18,00 & 25,53 & 7,44 & 8,44 \\
\hline \multirow[t]{3}{*}{ Waiting Time } & 5,16 & 3,05 & 4,25 & 19,00 & 14,38 & 9,00 & 12,77 & 3,72 & 4,22 \\
\hline & \multicolumn{9}{|c|}{ Zona-2 (Western Palu) } \\
\hline & \multicolumn{3}{|c|}{ Internode-8 } & \multicolumn{3}{|c|}{ Internode-9 } & \multicolumn{3}{|c|}{ Internode-10 } \\
\hline Headway & 4,09 & 1,32 & 2,54 & 23,75 & 25,50 & 10,29 & 14,64 & 38,75 & 28,75 \\
\hline \multirow[t]{3}{*}{ Waiting Time } & 2,05 & 0,66 & 1,27 & 11,88 & 12,75 & 5,15 & 7,32 & 19,38 & 14,38 \\
\hline & \multicolumn{9}{|c|}{ Zona-3 } \\
\hline & \multicolumn{3}{|c|}{ Segment-1 } & \multicolumn{3}{|c|}{ Segment-2 } & \multicolumn{3}{|c|}{ Segment-3 } \\
\hline Headway & 18,59 & 24,40 & 23,09 & 12,14 & 20,50 & 13,10 & 10,50 & 15,18 & 11,18 \\
\hline Waiting Time & 9,48 & 12,20 & 11,55 & 6,07 & 10,25 & 6,55 & 5,25 & 7,59 & 5,59 \\
\hline
\end{tabular}

Table 6. Passenger, Travel Time, Speed and Average Load Factor in Zone 1

\begin{tabular}{|c|c|c|c|c|c|c|}
\hline \multirow[b]{2}{*}{ No } & \multirow[b]{2}{*}{ Segmen } & \multirow[b]{2}{*}{$\begin{array}{c}\text { Distance } \\
\text { (Km) }\end{array}$} & \multicolumn{4}{|c|}{ Average } \\
\hline & & & $\begin{array}{c}\text { Passe } \\
\text { ngers } \\
\text { (Person) }\end{array}$ & \begin{tabular}{|c} 
Travelling \\
Time \\
(minute)
\end{tabular} & $\begin{array}{l}\text { Speed } \\
\text { (Kph) }\end{array}$ & $\begin{array}{c}\text { Load } \\
\text { Factor } \\
(\%)\end{array}$ \\
\hline \multirow{5}{*}{ 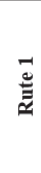 } & Donggala - Watusampu Boundary & 1,70 & 2 & 2.253 & 40,19 & 19,75 \\
\hline & Watusampu - Buluri & 4,50 & 3 & 9.753 & 38,19 & 37,04 \\
\hline & Buluri - Tipo & 1,50 & 3 & 8.587 & 35,78 & 38,27 \\
\hline & Tipo - City Center Boundary & 1,30 & 5 & 7.580 & 34,10 & 59,26 \\
\hline & Total & 9,00 & 3,47 & 28.173 & 37,07 & 38,58 \\
\hline \multirow{6}{*}{$\stackrel{\sim}{\stackrel{\Xi}{*}}$} & City Center Boundary - Tipo & 1,30 & 5 & 2.887 & 31,25 & 55,56 \\
\hline & Tipo - Buluri & 1,50 & 3 & 7.487 & 34,57 & 38,27 \\
\hline & Buluri - Watusampu & 4,50 & 2 & 8.420 & 36,41 & 27,16 \\
\hline & Watusampu - Donggala Boundary & 1,70 & 1 & 9.593 & 38,82 & 9,88 \\
\hline & Total & 9,00 & 2,94 & 28.387 & 35,26 & 32,72 \\
\hline & Average & 9,00 & 3,21 & 28.280 & 36,16 & 35,65 \\
\hline
\end{tabular}


Zone B cannot be collected to obtain the number of passengers, travel time, speed and load factor due to the moving city transportation service based on the desire of passenger travel (negotiation result).

Table 7. Passenger, Travel Time, Speed and Average Load Factor in Zone 3

\begin{tabular}{|c|c|c|c|c|c|c|}
\hline \multirow[b]{2}{*}{ No } & \multirow[b]{2}{*}{ Segmen } & \multirow[b]{2}{*}{$\begin{array}{c}\text { Distance } \\
(\mathbf{K m})\end{array}$} & \multicolumn{4}{|c|}{ Average } \\
\hline & & & $\begin{array}{c}\text { Passe } \\
\text { ngers } \\
\text { (Person) }\end{array}$ & \begin{tabular}{|c|} 
Travelling \\
Time \\
(minute)
\end{tabular} & $\begin{array}{l}\text { Speed } \\
(\text { Kph) }\end{array}$ & $\begin{array}{c}\text { Load } \\
\text { Factor } \\
\text { (\%) }\end{array}$ \\
\hline \multirow{6}{*}{ 氖 } & Donggala - Pantoloan Boundary & 1,50 & 2 & 2.540 & 40,32 & 27.16 \\
\hline & Pantoloan - Taipa & 6,20 & 4 & 7.407 & 36,60 & 40.74 \\
\hline & Taipa - Mamboro & 5,10 & 5 & 2.527 & 35,95 & 58.02 \\
\hline & Mamboro - Tondo & 4,30 & 5 & 2.680 & 29,34 & 54.32 \\
\hline & Tondo - City Boundary & 1,50 & 5 & 15.153 & 35,55 & 55.56 \\
\hline & Total & 18,60 & 4,24 & 30.307 & 35,55 & 47.16 \\
\hline \multirow{7}{*}{ 苞 } & City Boundary - Tondo & 1,50 & 6 & 2.687 & 29,35 & 49.38 \\
\hline & Tondo - Mamboro & 4,30 & 5 & 2.627 & 34,15 & 46.91 \\
\hline & Mamboro - Taipa & 5,10 & 3 & 7.753 & 35,54 & 43.21 \\
\hline & Taipa - Pantoloan & 6,20 & 2 & 2.493 & 40,62 & 32.10 \\
\hline & Pantoloan - Donggala Boundary| & 1,50 & 4 & 15.560 & 34,91 & 44.44 \\
\hline & Total & 18,60 & 4,11 & 31.120 & 34,91 & 43.21 \\
\hline & Average & 18,60 & 4,18 & 30.713 & 35,23 & 45.19 \\
\hline
\end{tabular}

passes at certain observation points (morning, afternoon and evening). Table 12 and Table 13 show the results of the calculation of the frequency of the city transport fleet in each zone.

Table 8. Vehicle Frequency / Hour

\begin{tabular}{|c|c|c|c|c|c|c|}
\hline \multirow{2}{*}{ Zone Code } & \multicolumn{2}{|c|}{ Peak } & \multirow{2}{*}{ Average } & \multicolumn{2}{c|}{ Off Peak } & \multirow{2}{*}{ Average } \\
\cline { 2 - 3 } & Rute 1 & Rute 2 & & Rute 1 & Rute 2 & \\
\hline 1 & 4,13 & 5,30 & 4,71 & 3,00 & 4,71 & 3,86 \\
\hline 2 & - & - & - & - & - & - \\
\hline 3 & 5,33 & 6,42 & 5,88 & 4,25 & 5,63 & 4,94 \\
\hline
\end{tabular}

Table 9. Variance of Each Zone

\begin{tabular}{|c|c|c|c|c|c|c|}
\hline \multirow{2}{*}{ Zone Code } & \multicolumn{2}{|c|}{ Rute 1 } & \multirow{2}{*}{$\begin{array}{c}\text { Variants } \\
\end{array}$} & Peak & Off Peak & \multicolumn{2}{|c|}{ Rute 2} & \multirow{2}{*}{$\begin{array}{c}\text { Variants } \\
\text { (\%) }\end{array}$} \\
\hline 1 & 4,13 & 3,00 & 72,73 & 5,30 & 4,71 & 88,95 \\
\hline 2 & - & - & - & - & - & - \\
\hline 3 & 5,33 & 4,25 & 79,69 & 6,42 & 5,63 & 87,66 \\
\hline
\end{tabular}

\subsection{Comparison of Performance with Standards}

In particular, the performance standard for city transportation does not yet exist, but the standards that will be used in this study are standards for city buses which can also apply to city transportation. The following shows the performance indicators of microbus city transportation in Palu City based on a combination of recommendations from the Ministry of Transportation and the World Bank. 


\subsubsection{Passenger Waiting Time}

The performance data of the passenger waiting time indicator based on the study zone show:

Zone 1, waiting time: morning (8.56 and 6.13) minutes, noon (13.59 and 9.72) and afternoon (10.50 and 6.13), zone 2 , waiting time: $<5$ minutes as many as 8 roads $(26.67 \%)$, $5 \leq \mathrm{WT}$ (minutes) $\leq 10$ as many as 13 sections $(43.33 \%), 10 \leq \mathrm{WT}$ (minutes) $\leq 15$ as many as 2 sections $(23.33 \%)$ and $>15$ minutes as much as 2 roads of $6.67 \%$. The value of the waiting time for other roads is not necessarily the same as the results for the surveyed roads because the angkot moves according to the agreement / negotiation between the user and the driver regarding the destination of the trip to be aimed. Zone 3, waiting times are: morning $(9.48,6.07$ and 6.55) minutes, noon (12.20, 10.25 and 7.59) and afternoon (11.55, 6.55 and 5,59$)$.

Based on the results of the analysis and observations of city transportation services associated with a waiting time performance indicator of 5 to 10 minutes, it can be explained:

- Variation in the waiting value is due to the fact that city transportation sometimes does not arrive at the end of the trip and has made a U-turn maneuver because the land use conditions are not promising to get passengers (zones 1 and 3 ),

- Observation of passenger waiting times in zone 2 was carried out in the city center on several roads that were thought to be used by public transportation to pick up / drop off passengers, so the results of this average waiting time did not reflect the actual condition because it could change at any time.

- Results of the recapitulation of waiting time services for the zone under review; $<5$ minutes is $20.00 \%, 5 \leq \mathrm{WT}$ (minutes) $\leq 10$ is $53.33 \%$ and $>10$ minutes is $26.67 \%$,

Based on existing public transport service standards, it means that angkot services in terms of waiting time have a fairly good performance apart from $20 \%$ of the segments and road segments that are observed to exceed the standard in more than 15 minutes.

\subsubsection{Traveling Time}

The results of data analysis on the travel time indicator show that the value of the zone 1 route is $(28,174$ and 28,280$)$ minutes, and the zone 3 route is $(30,301$ and 30,713$)$ minutes, while zone 2 cannot be measured against the travel time.

The value of the travel time can be influenced by several factors such as: speed, route length, traffic conditions, and time to negotiate the destination of the trip. Zone 1 route has a route length of $9.00 \mathrm{~km}$ and zone 2 route $18.60 \mathrm{~km}$ along this road, the speed can still be maintained, but after entering urban areas the length of the route that must be traversed is unpredictable because the movement of the angkot is very much determined by the agreement. between users and public transportation drivers / operators.

The travel time on the route zone 1 and zone 2 is quite short because the use of land use as a generator and towing movement is still lacking so that the speed of the angkot can still be maintained, but after entering the city the travel time begins to decline due to land use use that begins to meet and towing areas movement with the fluctuation of traffic flow which is quite dense at certain hours.

\subsubsection{Speed}

The results of the analysis of the speed indicators on the zone 1 route of $36.16 \mathrm{~km} / \mathrm{h}$ and the zone 3 route of $35.23 \mathrm{~km} / \mathrm{h}$ are both above the predetermined standard limit of 10-12 
$\mathrm{km} /$ hour but are still below the maximum limit ( $40 \mathrm{~km} /$ hour) so that the performance is good, but after entering the 3 -speed zone urban area can no longer be predicted because the traversed route changes according to the request of angkot users.

The zone 1 route has a tendency to go at high speed because the area of the trajectory is still empty from the influence of other traffic flows and the distance between residential areas is quite far and the number of movement-attracting areas is still very limited. - Buluri with speeds approaching $40 \mathrm{~km} /$ hour.

On the zone 3 route the speed is unstable, so this is detrimental to passengers. In segments traversed at low speed, passengers will wait too long to get an angkot. This condition will not be a problem for passengers whose position is in high-speed segments because they can quickly get public transportation and reach their destination quickly.

\subsubsection{Load Factor}

The load factor analysis is intended to measure the capacity of passengers each time, so that from the load factor data, it can be seen whether each angkot on the route is able to carry passengers at maximum capacity.

Based on the results of the load factor analysis, all of the routes surveyed were below standard. Zone 3 route has the highest load factor $(36.23 \%)$, followed by zone 1 route with load factor $(35.65 \%)$ and zone 2 route in urban areas cannot be predicted because the route is uncertain.

On route zone 1 , the segment with a maximum load factor for route 1 is Tipo - City Center Limit (59.26\%) and the segment with a minimum load factor is the boundary of Donggala Regency - Watusampu (19.75\%), while on route 2 the load factor Maximum City Center Limit - Tipo (55.56\%) and the segment with a minimum load factor is Watusampu Donggala Limit (9.88\%). The boundary of Donggala - Watusampu regency is natural if it is quiet from passengers because the length of the segment is relatively short, residential settlements are tenuous and the facilities for attracting movement are still limited, in contrast to Buluri - Tipo - City Limits where residential settlements have begun to meet with the large number of housing locations built by carriers and availability multiple movement towing facilities.

On the zone 3 route, the segment with the maximum load factor for route 1 is Tondo City Boundary (55.56\%) and the segment with a minimum load factor is the Donggala Pantoloan Regency boundary (27.16\%), while on route 2 the maximum load factor The City Center Boundary - Tondo (49.38\%) and the segment with a minimum load factor is Taipa - Pantoloan (32.10\%).

\subsubsection{Frequency}

Frequency analysis is intended to measure the performance of city transportation in providing services to its users.

Based on the data from the analysis of the frequency of vehicles during busy and offpeak hours for each route, it can be seen that for zone 1 and zone 3 the number of vehicles passing during peak hours is less than during off-peak hours. This situation occurs because at the time of approaching rush hour, many vehicles are scrambling to move to locations that are predicted to be many passengers. Due to the small number of passengers on the route that is passed so that if the frequency is increased it will cause losses to the driver / operator. Zone 1 and zone 3 routes seem to have provided good service by distinguishing between busy and non-busy times. 
If it is seen from the calculation, it can be analyzed that the variance between the frequency of vehicles when busy and not busy is relatively high. Thus it can be said that the high variance describes an unstable demand between the number of vehicles and the availability of potential angkot service users.

\section{Conclusion}

By implementing fixed routes for city transportation services in the city of Palu, it is hoped that the indicators of service performance can meet the predetermined standards because city transportation (mikrolet) is getting more regular and will gradually attract users because the place to wait is clear, long waits are measurable, there is no need to negotiate travel destinations and predictable travel times. In addition, it is hoped that captive users can be enthusiastic about using city transportation again in meeting their daily needs and can also attract users who have the choice to use city transportation as an alternative mode of travel. Another positive impact of implementing a fixed route is that it can reduce the level of congestion, air pollution, noise and vibration because city transportation provides services to its users according to a predetermined route.

\section{References}

[1] Adisasmita, S.A., (2011). Transportasi dan Pengembangan Wilayah, Konsep Dasar Transportasi dalam Pembangunan; Transportasi Menciptakan Place Utility dan Time Utility. Yogyakarta: Graha Ilmu.

[2] Bruton, M.j, 1985., Introduction to Transport Planning. Third Edition. London: Anchor Brendon Ltd.

[3] Chapin, F. Stuart Jr., and E. Keiser. 1979. Urban Land Use Planning, Third Edition. Chicago: University of Illinois Press.

[4] Davidson,O. 2001. Climate Change and Technology Transfer. Energy and Development Research Centre. University of Cape Town. Tasmania.

[5] Edwards,J.D.(Editor). 1992. Transportation Planning Handbook. Prentice Hall. New Jersey.

[6] Tamin, Ofyar Z. (2000) Perencanaan dan Permodelan Transportasi. Edisi ke-2. Bandung: Penerbit ITB.

[7] Putri, E.P., (2009). Keterkaitan Antara Karakteristik Pelayanan Paratransit dengan Pola Keruangan Kawasan di Kelurahan Ancol dan Sekitarnya, DKI Jakarta. Universitas Gadjah Mada.

[8] Vuchic, V.R., 1981, Urban Public Transportation and technology, Prentice Hall, New Jersey.

[9] Undang Undang Nomor 22 Tahun 2009 Tentang Lalu Lintas dan Angkutan Jalan Raya.

[10] Badan Pusat Statistik, Tahun 2015. Kota Palu Dalam Angka.

[11] Suwarjoko Warpani, 1990, Merencanakan Sistem Perangkutan, ITB.Bandung

[12] Ditjen Perhubungan Darat Departemen Perhubungan. 1996. Pedoman Teknis Penyelenggaraan Angkutan Penumpang Umum di Wilayah Perkotaan dalam Trayek Tetap dan Teratur. Jakarta. 